graduate's curriculum. Certainly the London Medical Student will find that the emphasis on applied and diagnostic bacteriology is also that of the examiners in the subject, and it will find support from the other teachers in the universities. Professor Hare's own experiences in epidemiology and virus diseases, no less than in bacteriology, prevent the book from being narrow and unbalanced.

It is good to find that the fungus infections have been placed in close proximity to actino-mycosis: a position which will appeal to the student and possibly persuade him not to regard them as something isolated and difficult. The success or failure of the book will probably depend on whether the students find it readable as well as informative.

The references, usually about three to a page are interesting in including original publications and modern reviews next to each other, so that we find 1887 and 1954 in close juxtaposition. The students working for a Pass Degree would be well advised to look at this book.

W.H.H.

\section{PEPTIC ULCER}

\section{Diagnosis and Treatment}

By Clifford J. Barborka, M.D., M.S., D.Sc., F.A.C.P. and E. Clinton Texter, JR., M.D. Pp. xiii +290 , with 33 illustrations. London: J. \& A. Churchill Ltd. 1955. 50s.

This is an up-to-date American account of modern ideas on the management of this exceedingly common complaint. The style tends to be verbose, but not to the extent of obscuring the authors' meaning.

The thorny question of the mechanism of pain production in ulcer is fairly presented and a synthesis of the conflicting theories is attempted. However, in the reviewer's opinion, the chasm separating the two main parties is far wider and deeper than the authors imagine.

Anticholinergic drugs, of the banthine series, receive a whole chapter to themselves. Enthusiasm for these drugs has been cooler in this country than in the United States but, as the authors point out, they are valuable in relieving severe pain during uncomplicated exacerbations.

The 'psychosomatic' aspect of peptic ulcer is moderately and sensibly treated. The authors' attitude may be summed up by their statement that ' good, informal psychotherapy can be carried out by the practitioner who is possessed of common sense.' This attribute would be valuable in many fields of psychosomatic medicine.

Two omissions seem serious. Firstly, in a text of this size and detail some mention should have been made of peptic ulceration in association with hiatus hernia. Secondly, in the treatment of pyloric stenosis nothing is said of the pathology and treatment of the profound electrolyte disturbances which follow prolonged vomiting, and their serious effect on kidney function. Even if surgery is required for relief of the obstruction, it should be a point of honour for the physician to present his patient to the surgeon in a fit state for operation.

Gastric ulcer receives a separate chapter, but even so the reviewer feels that more stress should have been laid on the differences between gastric and duodenal ulcer. Though the management in many cases is similar in the two diseases, evidence is accumulating that they are of totally different aetiology.

P.H.S.

\section{A TEXTBOOK OF SURGICAL PATHOLOGY}

By C. F. W. Illingworth, C.B.E., M.D., Ch.M., F.R.C.S., and B. M. Dick, M.B., F.R.C.S. Seventh Edition. Pp. viii +730 , with 322 illustrations. London: J. \& A. Churchill Ltd. 1956. 63s.

Like the other books with which Professor Illingworth is connected, this has a clarity of style and a commonsense outlook which will be welcomed by all readers, and particularly by the overburdened Final Fellowship candidate.

In general it has been brought well up to date in this edition, and it is a reliable and comprehensive guide to surgical pathology. A very few sections, such as those on hydronephrosis and stricture of the ureter, require re-writing because they are obscure, and in one or two places, such as the account of melanomata, important work has been omitted.

Apart from a few such instances the book is a first-class production, with good illustrations and helpful references. It can be thoroughly recommended.

H.L.B.

\section{THE CHRISTCHURCH HOSPITAL MEDICAL MANUAL}

Edited by C. T. Hand Newton, D.S.O., M.D., F.R.A.C.P., F.R.C.S. Fourth edition. Pp. 173 . Christchurch: N. M. Peryer Ltd. 1956. New Zealand. Price 27 s.

The scope of this book can only be described as ' parochial.' Most of the matter in it is of interest only to those working in the Christchurch Hospital (N.Z.), including such details as how to make an appointment wih the X-ray department (ring the appointment clerk, extension No. 792). Of the remaining material, there are sections dealing with the various laboratory investigations and their interpretation; this ground is better covered in many standard works on the subject. There is, however, a thoughtful little section on electrolyte balance which many house officers would find helpful. The price seems excessive for anyone who does not need a guide to Christchurch Hospital. 